\title{
The Application of the Triple Bottom Line Approach to Sustainability Assessment: the Case Study of the UK Automotive Supply Chain
}

\author{
Susana Azevedo' ${ }^{1}$, Miguel Barros² \\ ${ }^{1}$ CEFAGE-UBI - Department of Business and Economics, University of Beira Interior (Portugal) \\ ${ }^{2}$ Department of Electromechanical Engineering, University of Beira Interior (Portugal)
}

sazevedo@ubi.pt, M6575@ubi.pt

Received: May 2016

Accepted: February 2017

\section{Abstract:}

Purpose: The objective of this paper is to assess the level of sustainability of the UK automotive supply chain (SC) considering simultaneously the three dimensions of sustainability (economic, social and environmental) representing the Triple Bottom Line (TBL) approach.

Design/methodology/approach: The assessment of the automotive SC' sustainability is based on the framework proposed by Salvado, Azevedo, Matias and Ferreira (2015) and uses the Simple Additive Weighting (SAW) method to aggregate economic, environmental and social indicators into a unique index. A case study on the UK automotive industry is used and the data to perform this study is collected from the sustainability reports of the UK' automotive companies from 1999 to 2014.

Findings: The proposed framework represents an important benchmarking tool, offering managers the opportunity for assessing the sustainability behaviour of their supply chains and compare it with other supply chains. Once identified the dimension of sustainability where the supply chain is worst performer managers can work closer to their supply chain' partners in order to improve the performance of those dimension of sustainability.

Research limitations/implications: One limitation of the suggested approach is related to the ambiguity associated to the selection process of the sustainability' indicators and the definition of weights for each sustainability' dimension. 
Practical implications: The assessment of the SC sustainability by using the suggested framework to compute a SC sustainability index offers managers an opportunity for assessing the level of sustainability of each individual company and the corresponding SC in a very easy way. It also represents an opportunity for improving company performance. In this way managers can use the information on the sustainability index to help adjusting their company's behaviour and improving their economic, social and environmental performance.

Originality/value: The proposed framework represents a contribution in the area of index construction and a valuable component of organizational management systems and monitoring programs.

Keywords: sustainability, framework, composite index, supply chain, automotive industry

\section{Introduction}

Companies are shifting from a conventional economic perspective of business to a more sustainable business model involving economic, social and environmental concerns in their operations. This is because managers recognise that sustainability has important impacts on their business representing new sources of competitive advantage and a proxy for quality management (Berns, Townend, Khayat, Balagopal, Reeves, Hopkins \& Kruschwitz, 2009).

The study of sustainability has evolved from focusing on the individual company to a supply chain perspective (Salvado et al., 2015; Seuring \& Muller, 2008; Penfield, 2014; Beske \& Seuring, 2014; Schaltegger \& Burritt, 2014). The main reason for that is the recognition that the supply chain management contributes for improving organizational effectiveness, competitiveness, customer service and profitability. It represents also a crucial influence on the increased concerns on sustainability of businesses. In addition to the implementation of practices that promote the overall efficiency of the individual company and corresponding supply chain, more attention should also be given to social, economic and environmental issues.

The concept of sustainability has three interdependent and interrelated components in common: society, environmental and economy. These components are consistent with the notion of the triple bottom line (TBL): people, planet and profit (Harris, Wise, Gallagher \& Goodwin, 2001; Pava, 2007). Companies are facing pressures from different stakeholders to act according to sustainability strategies (Erol, Sencer \& Sari, 2011). However, although some companies claim to endorse sustainability at strategic and 
operational level, it appears that the frameworks used to support these activities do not adequately account for environmental and social issues. It is critical to consider the sustainability as part of normal business processes (Labuschagne \& Brent, 2005). The literature provides numerous tools and reporting formats which allow companies to demonstrate their commitment to sustainability concerns (Delai \& Takahashi, 2011), as in the case of the sustainability reports.

Sustainability already represents an area of concern for all sectors of the economy. Companies have to comply with an extensive set of directives and regulations concerning $\mathrm{CO}_{2}$ emissions, pollution and noise emissions, product and component safety, product reusability, recyclability and recoverability, among others (Petrescu-Mag, Petrescu, \& Muntean, 2015). These regulations are mostly concerned with technical issues. In addition to these regulatory pressures, most industries are facing a number of challenges, including globalization, the ongoing economic crisis in Europe and pressures from labour unions for better working conditions and wages. Moreover, integrating sustainable operations requires companies to engage in supply chain management practices as a way of becoming more competitive (Seuring \& Müller, 2008; Sarkis, 2003).

The sustainability of industries is based on the behaviour of all partners in the supply chain. Therefore, tools to capture the sustainability of supply chains are needed. In addition, more friendly tools are need to support the systematic process of searching for best practices, innovative ideas and efficiencies that lead to the continuous improvement of SC performance considering the TBL perspective.

Dos Santos and Brandi (2015) suggested the use of composite indexes to measure supply chain sustainability. They stress the need for more theoretical research to develop principles that take into account the complexity of supply chain structures. Despite the various studies on the construction of composite indexes (in general and for the sustainability field in particular), many of them focus more on the territory as unit of analysis (Pérez, Guerrero, González, Pérez \& Caballero, 2013; Wang, Lam, Harder, Ma \& Yu, 2013; Moreno-Pires \& Fidélis, 2012). Moreover, there are few studies that focus on sustainability indices for both individual companies and their corresponding supply chains, and considering the three dimensions of sustainability (social, economic and environmental). To address these gaps this paper proposes a sustainability index considering TBL perspective and suggesting economic, social and environmental indicators for supply chain.

This paper is organized as follows. First a theoretical background on the sustainability concept is presented, including sustainability indicators and indices. Then a sustainability framework is described, illustrating all the steps associated to the construction of the sustainability index. Finally, the conclusions are drawn. 


\section{Theoretical Background}

A more sustainable form of business requires that the environmental, economic and social issues must be integrated into supply chain management (Ahi \& Searcy, 2013; Seuring \& Muller, 2008). So, an integrated approach is necessary when considering the supply chain perspective (Vachon \& Klassen, 2006). Kogg and Mont (2012) argue that companies are increasingly pressed by stakeholders to address not only environmental but also social aspects at different tiers in their supply chain. Among the diversity of supply chain management issues, the ability to avoid risks (environmental and social) and increase performance (economic) is considered critical to ensuring supply chain sustainability (Seuring \& Muller, 2008; Gimenez \& Tachizawa, 2012). Azevedo, Govindan, Carvalho and Cruz-Machado (2012) state that the management practices deployed by the individual companies belonging to the same supply chain will affect overall sustainability.

The development of supply chain performance systems that include sustainability is challenging (Taticchi, Tonelli \& Pasqualino, 2013). Even without considering all the three dimensions of sustainability, and despite the numerous studies (e.g. Shepherd \& Günter, 2006; Gopal \& Thakkar, 2012), there is no consensus on how to measure supply chain performance. Clivillé and Berrah (2012) clarify that assessing overall supply chain performance requires a company's overall performance and the identification of the interaction between the companies involved.

Companies have been pressed not only to change the way they do business but also to monitor and report on more than just their economic performance. As a response, some efforts have been performed to establish sustainability indicators and measures at the business level. Delai and Takahashi (2011) point out some well-known guidelines, frameworks and measurement systems on sustainability: i) Global Reporting Initiative - GRI; ii) sustainability metrics of the Institution of Chemical Engineers; iii) the Dow Jones Sustainability Index; iv) Triple Bottom Line Index (TBL); v) the ETHOS Corporate Social Responsibility Indicators; vi) the OECD guidelines for multinational enterprises. Some sustainability indicators have also been suggested in the literature (Veleva \& Ellenbecker, 2001; Azapagic, 2004; Krajnc \& Glavič, 2005; Labuschagne, Brent \& van Erck, 2005; Matopoulos \& Bourlakis., 2010; Hai, Hai, Ha, Ha, Dai, Hoa et al., 2014; Salvado et al., 2015).

Despite the several sustainability measurement initiatives, only few have integrated simultaneously the environmental, economic and social dimensions (Labuschagne et al., 2005; Singh, Murty, Gupta \& Dikshit, 2009; Veleva \& Ellenbecker, 2001). Moreover, an important drawback which represents a major barrier for implementing sustainability strategies is the lack of consensus on sustainability indicators (Searcy, Karapetrovic \& McCartney, 2005; Sikdar, 2003; Veleva \& Ellenbecker, 2001). 
Erol et al. (2011) suggest a composite index for measuring supply chain sustainability, stressing that using too many indicators complicates the sustainability assessment process. They also argue that a proper approach to management decisions, such as with sustainable supply chains, implies involving various participants and perspectives; therefore, it is a challenge to reduce all dimensions to a single measure. To overcome this difficulty, they propose the use of multi-criteria evaluation methodologies.

The sustainability assessment has been focused in several manufacturing sectors, such as the steel industry (Singh, Murty, Gupta \& Dikshit, 2007), chemical industry (Beloff \& Tanzil, 2006), breweries (Tokos, Pintarič \& Krajnc, 2012), as well as a number of other sectors, such as the retail sector (Erol et al., 2011): finance sector (Kapur \& Dhanrajani, 2013); Biomass sector (Camarillo, Stringfellow, Jue \& Hanlon, 2012), health care (Ramirez, West \& Costell, 2013).

There are also some advances in measuring the environmental performance of companies and their respective supply chains. Azevedo, Govindan, Carvalho and Cruz-Machado (2013) suggest an "Ecosilient Index" to assess the greenness and resilience of automotive companies and the corresponding supply chain. In the proposed composite index the behaviour of companies is assessed by looking at the implementation level of a set of resilient and environmental practices, and the supply chain behaviour is assessed by aggregating the individual company behaviours. Wang, Zhang, Liu, Liu and Zhang (2005) proposed a performance assessment approach to assess green supply chain performance considering six factors: financial value, environmental protection, information value, customer service, cost, and operational flexibility. Tsoulfas and Pappis (2008) propose a set of environmental performance indicators and multi-criteria decision-making methodologies to measure the extent to which environmental principles are fulfilled along the supply chain. Savino, Manzini and Mazza (2015) use a global impact matrix where the supply chain carbon footprint (environmental impact) is mapped against the unit cost (economic impact).

Azevedo et al. (2012) propose a set of performance measures covering economic, environmental, and social perspectives to evaluate the influence of green and lean upstream supply chain management practices on the sustainable development of businesses, based on the Global Reporting Initiative (GRI). The GRI is used because it is considered to provide the most widely recognized guidelines for reporting economic, environmental, and social dimensions of sustainability (Skouloudis, Evangelinos \& Kourmousis, 2007; Christofi, Christofi \& Seleshi, 2012). The GRI gives managers the possibility to become more aware of the organisation's actual performance and impacts in relation to sustainability. In fact, the GRI enables a snapshot of the organisation's sustainability position and also provides both internal and external stakeholders, information on the process as well as its outcomes (Gray, Milne \& Buhr, 2014). 
There are many sustainability indices in the literature which are used in different contexts, with different characteristics and associated to various advantages and disadvantages such as: i) Dow Jones Sustainability Index, which covers economic, environmental and social aspects with equal weights. In this index the requirements concerning sustainability aspects are more wide-reaching than in other sustainability indices (López, García \& Rodríguez, 2007); ii) Environmental Sustainability Index (ESI), includes ecological, economic and social dimensions (Siche, Agostinho, Ortega \& Romeiro, 2008); iii) Ecological Footprint Analysis (EFA), is a measure of how much productive land and water an individual, a city, a country, or humanity requires to produce the resources it consumes and to absorb the waste it generates, using prevailing technology (Wackernagel, 2014); iv) Genuine Progress Indicator (GPI), is an aggregate index formed by 20 sub-indicators of which 7 indicators reflect a growth in welfare and 13 indicators reflect a reduction in welfare. GPI includes social and environmental benefits and costs as well as those of the standard economic variety (Singh et al., 2009).

Some sustainability assessment frameworks can also be found. Bautista, Enjolras, Narvaez, Camargo and Morel (2016) propose a framework to assess the sustainability of the biodiesel industry using a survey to define and validate the principles and criteria importance. Azapagic, Stamford, Youds and Barteczko-Hibbert (2016) suggest a decision-support framework integrating economic, environmental and social sustainability with life cycle thinking and focusing on sustainable production and consumption. This framework was validated using case studies from the energy sector. Resta, Dotti, Pinto, Bandinelli, Rinaldi and Ciarapica (2014) propose a theoretical framework for mapping practices associated only to environmental sustainability in the Textile, Clothing and Leather (TCL) sectors. Also, Liew, Hassim and Denny (2015) developed a systematic framework for sustainability assessment of biodiesel production pathways focusing on the engineering stage.

Besides the existence of some frameworks on sustainability most of them are applied in different sectors, not focusing on the Triple Bottom Line, not oriented for the supply chain and using different methodologies. The proposed framework seeks to respond to this gap in the literature.

The hierarchical approach followed in this study considers that the supply chain is composed by a set of n companies, and the overall supply chain sustainability will be affected by the aggregation of the three dimensions of sustainability: economic, social and environmental. 


\section{Framework to Asses the Sustainability of the Supply Chain}

The framework proposed in this study is based on Salvado et al. (2015) however some differences exist, such as: the number of stages, the method used for weighting each dimension of sustainability (social, economic and environmental), the selection process of indicators and the type of indexes proposed.

The framework applied in this study comprises six steps as a way of computing the supply chain sustainability index through the aggregation of three sub-indexes $\left(\left(I_{C_{-} S U S T}\right)^{\text {overall }}\right)(j=1$ economic dimension; $j=2$ environmental dimension; and $j=3$ social dimension).

Each sub-index is computed using a set of indicators $I_{i, j}^{\varepsilon}$. In a second phase, the supply chain sustainability index $\left(\left(I_{C \_S U S T}\right)^{\text {overall }}\right)$ is computed by aggregating the sustainability sub-indices.

The assessment of the supply chain sustainability is performed using the following steps adapted from Salvado et al. (2015): 1) Selection of sustainability indicators and data collection; 2) Computing weights using the Delphi technique; 3) Normalization of the sustainability indicators; 4) Choice of the aggregation method; 5) Computing the sustainability sub-index by sustainability dimension; 6) Computing the supply chain sustainability index.

\section{$1^{\text {st }}$ Step - Selection of Sustainability Indicators and Data Collection}

Supply chain sustainability indicators must be measurable and thus verifiable. As companies modify their practices from time to time they should also be dynamic enhancing benchmarking and monitoring over time. It is important that they are included in the total evaluation of the company's operations, products and services and also in the decision-making process (Tsoulfas \& Pappis, 2008). According to Erol et al. (2011) the indicators should follow three criteria: they should be measurable, data should be available for a particular indicator and the indicators should be related to the type of supply chain considered. In this study a set of economic, social and environmental indicators was identified from the sustainability reports of the UK automotive companies considering the guidelines given by the GRI. This method is used since the GRI has been focused by researchers and professionals in the sustainability reports (GRI, 2013). 


\section{$2^{\text {nd }}$ Step - Computing Weights Using the Delphi Technique}

The Delphi technique is used to obtain a set of weighted economic, social and environmental indicators. Each indicator is measured using a score between 1 and 5, with 1 representing "not important" and 5 representing "extremely important". Also the importance of each sustainability dimension (social, economic and environmental) is rated using the Delphi technique.

The Delphi technique is a highly formalized method of communication that is designed to extract the maximum amount of unbiased information from a panel of experts (Chan, Yung, Lam, Tam \& Cheung, 2001). It offers important advantages in situations where it is crucial define areas of uncertainty or disagreement, as is in this case. It also allows uncertainty to be assessed in a quantitative manner. Therefore, the Delphi technique is appropriate to compute a set of weighted economic, social and environmental indicators to assess the level of sustainability of both individual companies and corresponding supply chain. According to Linstone and Turoff (1975) the next steps should be followed in preparing a Delphi study: i) defining and selecting the experts; ii) defining the number of rounds; and iii) designing the questionnaire structure in each study round. Generally, the number of rounds ranges from 2 to 7 and the number of participants varies between 3 and 15 (Rowe \& Wright, 1999).

The members of the Delphi panel could be professionals, working in environmental management, human resources management and economic performance. Once selected for the Delphi panel they are invited to participate in a meeting to complete an individual on-line questionnaire. All the completed questionnaires are then aggregated into a unique database and the consistency of the professionals' responses is determined using Kendall's coefficient. Kendall's coefficient of concordance is used to study the degree of association among rankings of several objects by several judges (Israel, 2009). Kendall's coefficient is determined using the Equation 1:

$$
W=\frac{12 R}{m^{2}\left(k^{3}-k\right)}
$$

Where:

$m$ represents the judges which rate the $k$ objects in rank order from 1 to $k$.

For each object $i$, the total rank is given by Equation 2 .

$$
R_{i}=\sum_{j=1}^{m} r_{i j}
$$

Where:

$r_{i j}=$ the rating judge $j$ gives to object $i$. 
$\mathrm{R}$ is then the sum of the squared deviations from $\bar{R}$, the mean of the $\mathrm{R}_{i}$ (Equation 3).

$$
R=\sum_{i=1}^{k}\left(R_{i}-\bar{R}\right)^{2}
$$

This coefficient varies between 0 , indicating no agreement between judges, and +1 indicating complete agreement among the judges on the ranking of various sustainability indicators. This coefficient is easily computed using a simple spreadsheet.

A rule of thumb suggested by Smith (2008) states that when Kendall's coefficient reaches 0.7 or higher, this can be interpreted as "strong agreement" or a ranking of high confidence. If, after a number of rounds, the coefficient is close to 0.7 , this can be taken to mean that an agreement has been reached by the panel members.

\section{$3^{\text {rd }}$ Step - Normalization of the Sustainability Indicators}

As the indicators that are integrated into a composite sustainability index are expressed in different units, the normalization of these units must be previously performed. In this study Minimum-Maximum method is used to normalize the indicators (Zhou, Tokos, Krajnc \& Yang, 2012). According to this method, each indicator with a positive impact on sustainability $\left(I_{i, j}^{+}\right)$is normalized using Equation 4:

$$
I_{N_{i, j}}^{+}=\frac{I_{i, j}^{+}-I_{i, j}^{+M I N}}{I_{i, j}^{+M A X_{-}-I_{i, j}^{+M I N}}}
$$

Where:

$I_{N_{i, j}}^{+}$- is the normalized indicator $i$ from the dimension of sustainability $j$ with positive impact on sustainability.

$I_{i, j}^{+}$- represents the indicator $i$ from the dimension of sustainability $j$ with positive impact on sustainability.

$I_{i, j}^{+M I N}$ - represents the lowest value of indicator $i$ from the dimension of sustainability $j$ with positive impact on sustainability. That is $I_{i, j}^{+M I N}=\min I_{i, j}^{+}$.

$I_{i, j}^{+M A X}$ - represents the highest value of indicator $i$ from the dimension of sustainability $j$ with positive impact on sustainability. That is $I_{i, j}^{+M A X}=\max I_{i, j}^{+}$. 
The normalization of indicators with a negative impact on sustainability is computed using the Equation 5.

$$
I_{N_{i, j}}^{-}=\frac{I_{i, j}^{-}{ }^{-1}-M I N}{I_{i, j}^{-M A X}{ }_{-I_{i, j}}^{-M I N}}
$$

Where:

$I_{N_{i, j}}^{-}$- is the normalized indicator $i$ from the dimension of sustainability $j$ with negative impact on sustainability.

$I_{i, j}^{-}$- is the indicator $i$ from the dimension of sustainability $j$ with negative impact on sustainability.

$I_{i, j}^{-M I N}$ - represents the lowest value of indicator $i$ from the dimension of sustainability $j$ with negative impact on sustainability.

$I_{i, j}^{-M A X}$ - represents the highest value of indicator $i$ from the dimension of sustainability $j$ with negative impact on sustainability.

\section{$4^{\text {th }}$ Step - Choice of the Aggregation Method}

Some methodological approaches can be found in the literature related to composite indicators and sustainability. The composite indicators consist of aggregating different indicators according to a pre-determined methodology (Gasparatos, El-Haram \& Horner, 2008). The composite indicators can be divided into the following categories (Niemeijer, 2002): i) data-driven, when data availability is the central issue concerning the development of the composite indicators and high-quality data must be provided, ii) theory-driven, when selecting the best possible indicators for composite indicators construction is done from a theoretical point of view, and iii) policy-driven, when the indicators are selected, especially for the monitoring of a certain policy.

Singh et al. (2007) propose a composite performance index using the analytical hierarchy process (AHP) to determine the weights at various levels. In a different approach Zhou, Ang and Poh (2007) propose a mathematical programming approach for constructing composite indicators using multiple criteria decision analysis (MCDA). Later, these same authors proposed a multiplicative optimization approach for constructing composite indicators, using the weighted product method (Zhou et al., 2007). In their approach the weights are generated by solving a series of multiplicative Data Envelopment Analysis (DEA) type models that can be transformed into equivalent linear programs. Cherchye, Moesen, Rogge and Puyenbroeck (2007) deployed DEA in the construction of the 
composite indicator enabling the normalization stage to be skipped. Hatefi and Torabi (2010) proposed a common weight MCDA-DEA approach for computing composite indicators. To deal with the uncertainty and vagueness in the weighting process Erol et al. (2011) proposed a fuzzy multiple criteria framework.

Nardo, Saisana, Saltelli and Tarantola (2005) provide elucidative guidelines on how to build composite indicators. According to these authors when using a linear additive aggregation technique, it is necessary to assure that the indicators are mutually independent. From an operational point of view this means that an additive aggregation function allows the marginal contribution of each variable to be assessed separately. In the context of MADM (Multiple Attribute Decision Making), the Simple Additive Weighting (SAW) method, also known as the weighted sum method, is one of the most commonly used aggregating methods for constructing a composite index - both in general and in an environmental context in particular (e.g. Kang, Kim \& Lee, 2002). The SAW method requires that the social, economic and environmental variables are preferentially independent, which may be difficult to satisfy. However, even if the assumption does not hold, the SAW method would also yield an extremely close approximation to the ideal value function (Yoon \& Hwang, 1995). Despite this limitation, the SAW method has been widely used in practice (e.g. Shafia, Mazdeh, Vahedi \& Pournader, 2011) due to its transparency and ease of understanding by non-experts.

\section{$5^{\text {th }}$ Step - Computing the Sustainability Sub-index by Sustainability Dimension}

The proposed approach also makes possible to assess sustainability sub-indices thorough the economic, social and environmental behaviour of supply chains. The Equation 6 can be used to compute the sub-indices $\left(I_{S_{j}}\right)$ for each sustainability dimension.

$$
I_{S_{j}}\left(\sum_{i} I^{+}{ }_{N_{i, j}}-\sum_{i} I_{N_{i, j}}\right)
$$

Where:

$I_{S_{j}}$ - it is the sustainability sub-index for the sustainability dimension $j$ ( $j=1$ economic dimension; $j=2$ environmental dimension; $j=3$ social dimension).

$I_{N_{i, j}}^{+}$- represents the normalized indicator $I$, with a positive impact on sustainability for the sustainability dimension $j$.

$I_{N_{i, j}}^{-}$-represents the normalized indicator $I$, with a negative impact for the sustainability dimension $j$. 


\section{$6^{\text {th }}$ Step - Computing the Supply Chain Sustainability Index}

The sustainability index is a function of the three sustainability sub-indexes. The sustainable sub-indices $I_{S_{j}}$ are weighted according to the professionals' perception of the importance of each sustainability dimension for the sustainability of the automotive industry. When applying the SAW method, the composite sustainability index for economic, social and environmental dimensions is computed using the Equation 7:

$$
I_{S j \_S U S T}=\sum_{j} I_{S} w_{j}
$$

Where:

$I_{S_{j}}$ - represents the sustainability sub-index, considering the sustainability dimension $j$ ( $j=1$ economic dimension; $j=2$ environmental dimension; $j=3$ social dimension).

$w_{j}$ - represents the weight associated to the sustainability dimension $j$,

$\sum w_{j}=1$ and $w_{j} \geq 0$

Equation 7 is used to evaluate the impact of economic, environmental and social behaviour of SC on its sustainability. There is a cumulative effect of the behaviour of each economic, environmental and social sub-index on the SC sustainability index.

The proposed overall sustainability index results from the operations developed by a set of companies belonging to the same supply chain. Since a company could simultaneously belong to more than one supply chain, the proposed index could also be used to assess the interactions among supply chains. This analysis is also important for performing sustainability benchmarking analysis among supply chains that belong to the same sector. In this way it is also possible to perform a ranking of supply chains based on the individual sustainability index. 


\section{Methodology}

This study intends to assess the level of sustainability by using the framework adapted from Salvado et al. (2015) in the automotive industry. To attain this objective a qualitative methodology based on case studies and content analysis is used. The content analysis is based on a longitudinal study of the sustainability reports from 1999 to 2014 and considering a case study of 25 companies from the UK automotive industry. The case study was chosen because it is considered adequate when a longitudinal study is developed representing a systematic way of observing the events, collecting data, analysing information, and reporting the results over a long period of time (Stake, 1995)? Moreover, and according to Perry (1998) and Rowley (2002), a case study approach is adequate when the boundaries of a phenomenon are not only still unclear but there is also no control over behavioural events. It is also adequate when the examination of the data is performed within the context of its use (Yin, 1984), that is, within the situation in which the activity takes place, as it is the case. The indicators collected to compute the suggested sustainability index are collected from sustainability reports edited by professionals from the automotive industry.

In this research, the boundaries (assessment of the sustainability performance of the automotive industry) are still relatively vague. To attain this objective, the content analysis methodology was used to identify a set of economic, social and environmental indicators in order to compute and analyse the sustainability index for the UK' automotive supply chain.

Yin (2002) states that case studies can be exploratory, descriptive or explanatory. They can be single or multiple case studies. Multiple case studies allow investigating different social, economic and environmental practices used by companies in the automotive SC of differing size and position in the SC and to determining the practices that more influence SC performance. The case study method has three distinct stages: design, collection and analysis.

Content analysis was also performed in this study, more precisely on sustainability reports. This method allows exploring strategic information that exists in organizational documents combined with powerful quantitative analysis (Tesch, 1990). The goal of content analysis is "to provide knowledge and understanding of the phenomenon under study" (Downe-Wamboldt, 1992, p. 314). Moreover, longitudinal research designs can be implemented because of the availability of comparable corporate information through time, such as annual reports or trade magazines (Kabanoff \& Keegan, 2007). The main advantage in using the content analysis is that it is nonintrusive and therefore does not suffer from researcher bias (Woodrum, 1984). Some researchers have emphasized the validity of annual reports, as it is the case of sustainability reports, because senior executives spend considerable time outlining the content of the report, sketching out much of it (Barr, Stimpert \& Huff, 1992) 
The content analysis can be conducted at two levels (Woodrum, 1984; Erdener \& Dunn, 1990): manifest content and latent content. The manifest content can be captured and revealed in a number of text statistics and the latent content focuses on deeper meaning of the text. The manifest content is followed in this study since the sustainability reports are analysed and common sustainability indicators (economic, social and environmental) identified.

\subsection{Sample}

To attain this objective, the automotive industry was chosen. This is because there are few industries as large, diverse and influential as the automotive industry but also, the management practices, organizational forms, and particularly the response to environmental pressures adopted by this industry are important in their own right, but also in terms of influencing many other business sectors. The products of this industry touch our daily lives not only by providing personal mobility for millions, but also by bringing the deterioration of local air quality in urban areas, along with global issues such as global warming, and the treatment of scrapped vehicles (Orsato \& Wells, 2007).

Geographically, the UK automotive industry was focused. The UK' automotive sector is very diverse having more than 40 companies manufacturing vehicles in some of the most productive plants in Europe. These include some of the world's global vehicle and engine manufacturers - Aston Martin, BMW (MINI and Rolls Royce), Ford, General Motors (Vauxhall), Honda, Jaguar Land Rover, Lotus, MG, Nissan, Toyota and Volkswagen (Bentley) - as well as specialist brands, such as McLaren and Morgan, and Triumph motorcycles. The presence of strong premium and niche vehicle producers in the UK mean that the UK is second in the world to Germany for premium vehicles (Automotive Council UK, 2013). There are also major manufacturers of commercial vehicles including Leyland Trucks, Dennis Eagle, Wright Bus, Optare and Alexander Dennis; and construction, agriculture and other specialist equipment makers Case New Holland, Caterpillar, JCB, Komatsu, Perkins, Terex and Twaites. The UK is fourth in the world for construction equipment and the second largest net exporter of construction equipment (Automotive Council UK, 2015).

The research data was collected from the sustainability reports of the following UK' companies: Alexander Dennis, Bentley Motors Limited, BMW Group, Bosch, CabAuto, Caterpillar, CEVA Logistics, DHL, Ford Motor Company Limited, General Motors UK Limited, GKN Driveline Limited, Honda (UK) and Honda of the UK Manufacturing Limited, IBC Vehicles Limited, Jaguar Land Rover Ltd, Leyland Trucks, PSA Peugeot Citroen Automobiles UK Limited, Michelin Tyre plc, Nissan Motor Manufacturing (UK) Limited and Nissan Technology Centre Group, Optare, Schaeffler, Toyota (GB) plc 
and Toyota Motor Manufacturing (UK) Limited, Unipart, Volkswagen Group (UK) Limited, Volvo Cars UK Limited, UYT.

\subsection{Data Collection}

A web-based search to gather sustainability reports published by UK companies belonging to the automotive supply chain was performed. Almost all published reports are available on web sites so that all stakeholders can read those (Herzig \& Godemann, 2010). That is why we decided to use the web as data source. In the study, we have included both the reports published on the companies' web sites and the reports that make part of collective data bases. A total of 25 sustainability reports from 1999 to 2014 belonging to different automotive companies were examined.

\section{Application of the Suggested Framework - Case Study}

In this section, the proposed Framework is applied using sustainability reports from UK automotive supply chain and using a time horizon from 1999 to 2014 (Table 1).

\begin{tabular}{|c|c|c|c|}
\hline & Identification & Main activity & Main product \\
\hline Company 1 & Alexander Dennis & Bus and coach manufacturing & $\begin{array}{l}\text { - Buses (Single Bus, Double Deck } \\
2 \text { axle, Double Deck } 3 \text { axle, } \\
\text { Coach) }\end{array}$ \\
\hline Company 2 & Bentley Motors Limited & Luxury automobile manufacturing & $\begin{array}{l}\text { - Handcrafter luxury cars } \\
\text { (Mulsanne, Flying Spur, } \\
\text { Continental range, Bentayga) }\end{array}$ \\
\hline Company 3 & $\begin{array}{l}\text { BMW Group (BMW, MINI, Rolls- } \\
\text { Royce) }\end{array}$ & $\begin{array}{l}\text { Luxury automobile, motorcycle } \\
\text { and engine manufacturing }\end{array}$ & $\begin{array}{l}-\mathrm{BMW} \text { vehicles and motorcycles } \bullet \\
\text { MINI vehicles } \bullet \text { Rolls-Royce } \\
\text { vehicles } \bullet\end{array}$ \\
\hline Company 3 & Bosch & $\begin{array}{l}\text { Development, manufacturing and } \\
\text { suppling of automotive } \\
\text { components }\end{array}$ & $\begin{array}{l}\text { - Auto parts and accessories } \\
\text { Automotive technology } \bullet \text { Bosh } \\
\text { service (repair, maintenance, travel } \\
\text { check-up) }\end{array}$ \\
\hline Company 5 & CabAuto & $\begin{array}{l}\text { Vehicle interior products' } \\
\text { manufacturer }\end{array}$ & $\begin{array}{l}\cdot \text { Seating } \bullet \text { Headliners } \bullet \text { Interior } \\
\text { trim } \bullet \text { Trunk systems } \bullet \text { Parcel tray } \\
\cdot \text { Door cards }\end{array}$ \\
\hline Company 6 & Caterpillar & $\begin{array}{l}\text { Design and manufacturing of } \\
\text { machinery, engines, diesel-electric } \\
\text { locomotives and finantial products }\end{array}$ & $\begin{array}{l}- \text { Constructing and mining } \\
\text { equipment } \bullet \text { Power systems } \\
\text { Attachments } \bullet \text { Parts }\end{array}$ \\
\hline Company 7 & CEVA Logistics & Logistics services provider & $\begin{array}{l}\text { - Aftermarket } \bullet \text { Finished vehicles } \bullet \\
\text { Inbound solutions } \bullet \text { Production } \\
\text { support } \bullet \text { Tires }\end{array}$ \\
\hline
\end{tabular}




\begin{tabular}{|c|c|c|c|}
\hline & Identification & Main activity & Main product \\
\hline Company 8 & DHL & Worlwide express deliveries & $\begin{array}{l}\cdot \text { Express services } \bullet \text { Freight } \\
\text { transportation } \bullet \text { Supply chain } \\
\text { solutions } \bullet \text { Mail }\end{array}$ \\
\hline Company 9 & Ford Motor Company Limited & $\begin{array}{l}\text { Automobile manufacturing and } \\
\text { distribution }\end{array}$ & $\begin{array}{l}\text { - Passenger cars } \bullet \text { Commercial } \\
\text { vehicles } \bullet \text { Supercars }\end{array}$ \\
\hline Company 10 & $\begin{array}{l}\text { General Motors UK Limited } \\
\text { (Vauxhall) }\end{array}$ & & $\begin{array}{l}\text { - Automobiles } \bullet \text { Commercial } \\
\text { vehicles }\end{array}$ \\
\hline Company 11 & GKN Driveline Limited & $\begin{array}{l}\text { Automotive components } \\
\text { manufacturing }\end{array}$ & - Automotive components \\
\hline Company 12 & $\begin{array}{l}\text { Honda (UK) and Honda of the } \\
\text { UK Manufacturing Limited }\end{array}$ & $\begin{array}{l}\text { Casting, pressing, welding, } \\
\text { painting and car assembly activities }\end{array}$ & $\begin{array}{l}- \text { Automobiles } \bullet \text { Motorcycles } \bullet \\
\text { Engines } \bullet \text { Lawn mowers }\end{array}$ \\
\hline Company 13 & IBC Vehicles Limited (Vauxhall) & $\begin{array}{l}\text { Vans and light commercial } \\
\text { vehicles' productiong and } \\
\text { assembly }\end{array}$ & $\begin{array}{l}\text { - Renault marque } \cdot \text { Nissan marque } \\
\text { - Opel/Vauxhall marque }\end{array}$ \\
\hline Company 14 & Jaguar Land Rover Ltd & $\begin{array}{l}\text { Car desing, development and } \\
\text { production }\end{array}$ & $\begin{array}{l}\cdot \text { Luxury sports cars } \bullet \text { Executive } \\
\text { saloon cars } \bullet \text { Off-road vehicles } \\
\text { (Land Rover) }\end{array}$ \\
\hline Company 15 & Leyland Trucks & $\begin{array}{l}\text { Truck manufacturing and parts } \\
\text { suppling }\end{array}$ & $\begin{array}{l}\text { - Trucks (DAF X6 Euro 6, DAF } \\
\text { CF Euro 6, DAF LF Euro 6) }\end{array}$ \\
\hline Company 16 & Michelin Tyre plc & $\begin{array}{l}\text { Bus, truck and car tyres } \\
\text { manufacturing }\end{array}$ & $\begin{array}{l}\cdot \text { Tyre } ・ \text { Travel assistance services } \\
\text { (maps, guides) }\end{array}$ \\
\hline Company 17 & $\begin{array}{l}\text { Nissan Motor Manufacturing } \\
\text { (UK) Limited and Nissan } \\
\text { Technology Centre Group } \\
\text { (Infiniti, Nissan) }\end{array}$ & Car manufacturing & $\begin{array}{l}\text { - Automobiles } \bullet \text { Luxury and high } \\
\text { performance cars (Infiniti) }\end{array}$ \\
\hline Company 18 & Optare & Bus design and manufacturing & $\begin{array}{l}\text { - Buses (Metrodecker, Versa, } \\
\text { Tempo, Solo, Metrocity) }\end{array}$ \\
\hline Company 19 & $\begin{array}{l}\text { PSA Peugeot Citroen Automobiles } \\
\text { UK Limited }\end{array}$ & $\begin{array}{l}\text { Automobiles and motorcycles } \\
\text { manufacturing }\end{array}$ & $\begin{array}{l}- \text { Cars } \bullet \text { Vans } \bullet \text { Motorcycles } \bullet \\
\text { Automotive parts } \bullet \text { Financing } \bullet \\
\text { Logistics }\end{array}$ \\
\hline Company 20 & Schaeffler & $\begin{array}{l}\text { Rolling element bearings } \\
\text { manufacturing }\end{array}$ & $\begin{array}{l}\text { - Components and systems for } \\
\text { engines, transmissions, chassis }\end{array}$ \\
\hline Company 21 & $\begin{array}{l}\text { Toyota (GB) plc and Toyota } \\
\text { Motor Manufacturing (UK) } \\
\text { Limited (Lexus, Toyota) }\end{array}$ & $\begin{array}{l}\text { Vehicle manufacturing and } \\
\text { assembly }\end{array}$ & $\begin{array}{l}\cdot \text { Luxury and hybrid cars } \bullet \text { Several } \\
\text { Toyota models (Avensis, Corolla, } \\
\text { Auris) }\end{array}$ \\
\hline Company 22 & Unipart (Unipart Logistics) & $\begin{array}{l}\text { Manufacturing, logistics and } \\
\text { consultancy services provider }\end{array}$ & $\begin{array}{l}\text { - Logistics } \bullet \text { Supply chain } \\
\text { consultancy }\end{array}$ \\
\hline Company 23 & $\begin{array}{l}\text { Volkswagen Group (UK) Limited } \\
\text { (Audi, SEAT, Skoda, Volkswagen } \\
\text { Passenger Cars, Volkswagen } \\
\text { Commercial Vehicles) }\end{array}$ & $\begin{array}{l}\text { Desing, manufacturing and } \\
\text { destribution in automotive sector }\end{array}$ & $\begin{array}{l}- \text { Automobiles } \bullet \text { Commercial } \\
\text { vehicles } \bullet \text { Engines } \bullet \text { Motorcycles } \bullet \\
\text { Turbomachinery }\end{array}$ \\
\hline Company 24 & Volvo Cars UK Limited & Luxury vehicles manufacturing & $\begin{array}{l}\cdot \text { Sport utility vehicles } \bullet \text { Station } \\
\text { wagons } \bullet \text { Sedans } \bullet \text { Coupes }\end{array}$ \\
\hline Company 25 & $\begin{array}{l}\text { UYT (changed name to CovPress } \\
\text { Assembly in 2015) (UYT) }\end{array}$ & $\begin{array}{l}\text { "One stop shop" for providing } \\
\text { engineering solutions for the } \\
\text { automotive sector }\end{array}$ & $\begin{array}{l}\cdot \text { Structural components } \bullet \text { Heat } \\
\text { shields } \bullet \text { Oil pans } \bullet \text { Pedal boxes } \\
\text { Suspension components }\end{array}$ \\
\hline
\end{tabular}

Table 1. Sample profile 


\section{$1^{\text {st }}$ Step - Selection of Sustainability Indicators and Data Collection}

The sustainability indicators used in this study were collected from the sustainability reports belonging to 25 UK automotive companies and considering also the guidelines given by the GRI (Table 2).

\begin{tabular}{|c|c|c|c|}
\hline & Indicator & $\begin{array}{l}\text { Unit of } \\
\text { measurement }\end{array}$ & Type of indicator* \\
\hline \multirow{3}{*}{$\begin{array}{l}\text { Economic } \\
\text { context }\end{array}$} & Automotive manufacturing sector turnover & f, billion & $I_{1,1}{ }^{+}$- The larger the better $(+)$ \\
\hline & Automotive sector value added & E, billion & $I_{2,1}{ }^{+}$- The larger the better $(+)$ \\
\hline & Total number of new cars produced & Quantity & $I_{3,1^{+}}$- The larger the better $(+)$ \\
\hline \multirow{5}{*}{$\begin{array}{l}\text { Environmental } \\
\text { context }\end{array}$} & Total combined energy use & GWh & $I_{1,2^{-}}-$The smaller the better $(-)$ \\
\hline & Water use per vehicle produced & $\mathrm{m}^{3} /$ unit & $I_{2,2^{-}}-$The smaller the better $(-)$ \\
\hline & $\mathrm{CO}_{2}$ equivalent per vehicle produced & tonnes & $I_{3,2^{-}}-$The smaller the better $(-)$ \\
\hline & Waste to landfill per vehicle produced & $\mathrm{kg} /$ unit & $I_{4,2^{-}}-$The smaller the better $(-)$ \\
\hline & Site waste for recycling per vehicle produced & $\mathrm{kg} /$ unit & $I_{5,2}{ }^{+}$- The larger the better $(+)$ \\
\hline \multirow{3}{*}{ Social context } & Number of lost-time incidents & Quantity & $I_{1,3^{-}}-$The smaller the better $(-)$ \\
\hline & Number of training days per employee & Quantity & $I_{2,3}{ }^{+}$- The larger the better $(+)$ \\
\hline & $\begin{array}{l}\text { Total number of employees }=\text { Automotive } \\
\text { manufacturing }+ \text { Automotive supply and use }\end{array}$ & Quantity & $I_{3,3}{ }^{+}$- The larger the better $(+)$ \\
\hline
\end{tabular}

Table 2. Sustainability indicators

These indicators were chosen because they make part of the GRI and are common to all the 25 sustainability reports of the research companies.

\section{$2^{\text {nd }}$ Step - Computing Weights Using the Delphi Technique}

The weights associated to each dimension of sustainability were obtained by using the Delphi technique. The success of the Delphi technique depends mainly on the careful selection of the panel members. A purposive approach was adopted to select this group of experts (Chan et al., 2001) using the following two criteria in order to identify eligible participants for this part of the study: i) having current/recent involvement in automotive industry research topics; ii) having a sound knowledge and understanding on sustainability. In order to obtain the most valuable opinions, only academics who met the two selection criteria were considered. As regards the selection of professionals from the industry the main criteria used was to work in a company belonging to the automotive supply chain. A total of 12 academics/professionals were invited to participate in this study. 
Virtual (by email) interviews were launched with academics/professionals to assess the importance of the economic, social and environmental behaviour of the companies to the sustainability of the automotive supply chain.

\section{Rounds of Delphi Questionnaires}

The first round of Delphi questionnaire was sent to the group of panel members by e-mail at the end of January 2016. The panel members formed by academics/professionals were informed about the Delphi technique. In the first round the 12 academics/professionals were asked to give their perception about the importance of the social, economic and environmental behaviour of the UK companies to the sustainability of the UK automotive supply chain. The responses of these 12 academics/professionals were collected. The results of this round were consolidated and presented to the panel members. Then they were requested to reconsider whether they would like to change any of their original choices in the light of the consolidated results from the first round. All the twelve questionnaires were completed at the end February 2016.

The order of importance of the sustainability dimensions was determined through the Delphi technique and considering the perception of academics/professionals, after the two rounds. Looking at Table 3 it is possible to highlight the following results: the most important dimension of sustainability is the environmental with a weight of $46 \%$, then the economic $(32 \%)$ while the social dimension was considered least important at $23 \%$.

As can be seen from the Kendall's coefficient of concordance the consistency of the academics/professionals rankings was lightly improved after the Round 2.

\begin{tabular}{|c|c|c|c|c|c|c|}
\hline \multirow{3}{*}{$\begin{array}{l}\text { Sustainability } \\
\text { dimensions }\end{array}$} & \multicolumn{6}{|c|}{ Statistics } \\
\hline & \multicolumn{3}{|c|}{ First round } & \multicolumn{3}{|c|}{ Second round } \\
\hline & Mean rating & Rank & Weighting & Mean rating & Rank & Weighting \\
\hline Social & 2.36 & 3 & 0.25 & 2.42 & 3 & 0.23 \\
\hline Economic & 3.15 & 2 & 0.34 & 3.41 & 2 & 0.32 \\
\hline Environmental & 3.89 & 1 & 0.41 & 4.91 & 1 & 0.46 \\
\hline $\begin{array}{l}\text { Number (n) } \\
\text { Kendall's Coefficient } \\
\text { of concordance (W) } \\
\text { Level of significance }\end{array}$ & \multicolumn{3}{|c|}{12} & & $\begin{array}{c}12 \\
0.669 \\
0.006\end{array}$ & \\
\hline
\end{tabular}

Note: For "Mean rating" $=1$ nothing important and $5=$ extremely important

Table 3. Results of round 1 and round 2 of Delphi technique for the importance of sustainability dimensions 


\section{$3^{\text {rd }}$ Step - Normalization of the Sustainability Indicators}

In this step the Minimum-Maximum method is used to normalize the economic, social and environmental indicators suggested in the previous section. The Equation 4 and Equation 5 were used respectively when the indicators have a positive or a negative impact on sustainability.

Since the indicators are expressed in different units, normalization is necessary (Equation 3). This makes possible to integrate the selected indicators into an aggregated index for sustainability assessment.

The normalization of indicators was computed using an Excel spreadsheet. In Table 4 the normalized indicators of social and environmental dimensions are present.

\begin{tabular}{|c|c|c|c|c|c|c|c|c|c|c|c|}
\hline & \multicolumn{3}{|c|}{ Economic dimension } & \multicolumn{3}{|c|}{ Social dimension } & \multicolumn{5}{|c|}{ Environmental dimension } \\
\hline & (1) & (2) & (3) & (4) & (5) & (6) & (7) & (8) & (9) & (10) & (11) \\
\hline & $I_{N_{1,1}}^{+}$ & $I_{N_{2,1}}^{+}$ & $I_{N_{3.1}}^{+}$ & $I_{3}^{+}$ & $I_{N_{2,3}}^{+}$ & $I_{N_{3.3}}^{+}$ & $I_{N_{1.2}}^{+}$ & $I_{N_{2.2}}^{+}$ & $I_{N_{3.2}}^{+}$ & $I_{N_{4.2}}^{+}$ & $I_{N_{5.2}}^{+}$ \\
\hline 1999 & 0.112 & 0.278 & 1.000 & $\mathrm{n} / \mathrm{a}$ & $\mathrm{n} / \mathrm{a}$ & 0.979 & 0.722 & $\mathrm{n} / \mathrm{a}$ & 0.686 & $\mathrm{n} / \mathrm{a}$ & $\mathrm{n} / \mathrm{a}$ \\
\hline 2000 & 0.039 & 0.133 & 0.803 & $\mathrm{n} / \mathrm{a}$ & $\mathrm{n} / \mathrm{a}$ & 0.866 & 1.000 & 0.743 & 0.714 & 0.588 & $\mathrm{n} / \mathrm{a}$ \\
\hline 2001 & 0.046 & 0.267 & 0.616 & $\mathrm{n} / \mathrm{a}$ & $\mathrm{n} / \mathrm{a}$ & 0.850 & 0.952 & 1.000 & 1.000 & 1.000 & $\mathrm{n} / \mathrm{a}$ \\
\hline 2002 & 0.126 & 0.256 & 0.788 & 0.998 & $\mathrm{n} / \mathrm{a}$ & 0.783 & 0.854 & 0.829 & 0.857 & 0.591 & $\mathrm{n} / \mathrm{a}$ \\
\hline 2003 & 0.175 & 0.233 & 0.823 & 1.083 & 1.000 & 0.843 & 0.727 & 0.200 & 0.143 & 0.234 & $\mathrm{n} / \mathrm{a}$ \\
\hline 2004 & 0.218 & 0.267 & 0.810 & 0.628 & 0.308 & 0.723 & 0.484 & 0.200 & 0.143 & 0.264 & 0.000 \\
\hline 2005 & 0.263 & 0.267 & 0.746 & 0.459 & 0.538 & 0.740 & 0.412 & 0.143 & 0.000 & 0.180 & 0.248 \\
\hline 2006 & 0.316 & 0.333 & 0.554 & 0.407 & 0.154 & 0.681 & 0.334 & 0.171 & 0.143 & 0.220 & 0.346 \\
\hline 2007 & 0.456 & 0.422 & 0.669 & 0.291 & 0.077 & 0.644 & 0.279 & 0.086 & 0.000 & 0.152 & 0.617 \\
\hline 2008 & 0.435 & 0.489 & 0.559 & 0.204 & 0.311 & 0.438 & 0.223 & 0.057 & 0.071 & 0.139 & 0.737 \\
\hline 2009 & 0.000 & 0.000 & 0.000 & 0.198 & 0.692 & 0.047 & 0.000 & 0.229 & 0.429 & 0.122 & 1.000 \\
\hline 2010 & 0.291 & 0.467 & 0.339 & 0.019 & 0.455 & 0.122 & 0.275 & 0.143 & 0.286 & 0.090 & 0.813 \\
\hline 2011 & 0.582 & 0.611 & 0.431 & 0.110 & 0.504 & 0.188 & 0.383 & 0.086 & 0.143 & 0.063 & 0.718 \\
\hline 2012 & 0.621 & 0.544 & 0.582 & 0.123 & 0.258 & 0.018 & 0.373 & 0.057 & 0.069 & 0.044 & 0.736 \\
\hline 2013 & 0.849 & 0.900 & 0.638 & 0.147 & -0.019 & 0.291 & 0.310 & 0.050 & 0.132 & 0.011 & 0.681 \\
\hline 2014 & 1.000 & 1.000 & 0.661 & -0.001 & 0.652 & 0.475 & 0.157 & -0.001 & 0.082 & -0.001 & 0.765 \\
\hline
\end{tabular}

(1) Automotive manufacturing sector turnover; (2) Automotive sector value added; (3) Total number of new cars produced; (4) Number of lost-time incidents; (5) Number of training days per employee; (6) Total number of employees = Automotive manufacturing + Automotive supply and use; (7) Total combined energy use (8) Water use per vehicle produced; (9) $\mathrm{CO}_{2}$ equivalent per vehicle produced; (10) Waste to landfill per vehicle produced; (11) Site waste for recycling per vehicle produced.

Table 4. Normalization of economic, social and environmental indicators 


\section{$4^{\text {th }}$ Step - Choice of the Aggregation Method}

The aggregation method used in this study is the Simple Additive Weighting method (SAW) which is also known as weighted linear combination or scoring methods.

\section{$5^{\text {th }}$ Step - Computing the Sustainability Sub-indices}

At this phase the weights are determined and indicators normalized, which makes possible that the sustainability sub-indices could be computed by economic, social and environmental dimensions and using Equation 6.

As regards the economic sub-index of sustainability as all the indicators chosen to translate the economic dimension of sustainability have a positive impact on the sustainability the factor $\sum_{i} I_{N_{i}, j}$ is not considered in the Equation 6. Being so, the economic sustainability index is computed by adapting Equation 6 and resulting in the following formula: $I_{S_{j}}=\sum_{i} I^{+}{ }_{N_{i, j}}$, as can be seen in Table 5.

As regards the environmental dimension and considering the sustainability reports of the 25 research companies, four indicators were identified with a negative impact on sustainability (total combined energy use, water use per vehicle produced, $\mathrm{CO}_{2}$ equivalent per vehicle produced, waste to landfill per vehicle produced) and only one with a positive impact (site waste for recycling per vehicle produced). The environmental sustainability index was computed across the sixteen years of analysis and using Equation 6 (Table 6). 


\begin{tabular}{|c|c|c|c|c|}
\hline Year & $\begin{array}{c}\text { Automotive } \\
\text { manufacturing } \\
\text { sector turnover } \\
\qquad I_{N_{1.1}}^{+}\end{array}$ & $\begin{array}{l}\text { Automotive sector } \\
\text { value added } \\
\qquad I_{N_{2.1}}^{+}\end{array}$ & $\begin{array}{l}\text { Total number of new } \\
\text { cars produced } \\
\qquad I_{N_{3.1}}^{+}\end{array}$ & $I_{S_{1}}=\sum_{i} I^{+} N_{i, 1}$ \\
\hline 1999 & 0.112 & 0.278 & 1.000 & 1.390 \\
\hline 2000 & 0.039 & 0.133 & 0.803 & 0.975 \\
\hline 2001 & 0.046 & 0.267 & 0.616 & 0.929 \\
\hline 2002 & 0.126 & 0.256 & 0.788 & 1.170 \\
\hline 2003 & 0.175 & 0.233 & 0.823 & 1.232 \\
\hline 2004 & 0.218 & 0.267 & 0.810 & 1.294 \\
\hline 2005 & 0.263 & 0.267 & 0.746 & 1.276 \\
\hline 2006 & 0.316 & 0.333 & 0.554 & 1.203 \\
\hline 2007 & 0.456 & 0.422 & 0.669 & 1.548 \\
\hline 2008 & 0.435 & 0.489 & 0.559 & 1.483 \\
\hline 2009 & 0.346 & 0.404 & 0.626 & 1.376 \\
\hline 2010 & 0.291 & 0.467 & 0.339 & 1.097 \\
\hline 2011 & 0.582 & 0.611 & 0.431 & 1.624 \\
\hline 2012 & 0.621 & 0.544 & 0.582 & 1.748 \\
\hline 2013 & 0.849 & 0.900 & 0.638 & 2.387 \\
\hline 2014 & 1.000 & 1.000 & 0.661 & 2.661 \\
\hline
\end{tabular}

Table 5. Determination of the economic sustainability index $\left(I_{S_{1}}\right)$

\begin{tabular}{|c|c|c|c|c|c|c|}
\hline & $\begin{array}{c}\text { Total } \\
\text { combined } \\
\text { energy use } \\
I_{N_{1,2}}^{-}\end{array}$ & $\begin{array}{l}\text { Water use } \\
\text { per vehicle } \\
\text { produced } \\
\qquad I_{N_{2,2}}^{-}\end{array}$ & $\begin{array}{c}\mathrm{CO}_{2} \\
\text { equivalent } \\
\text { per vehicle } \\
\text { produced } \\
I_{N_{3,2}}^{-}\end{array}$ & $\begin{array}{l}\text { Waste } \\
\text { to landfill } \\
\text { per vehicle } \\
\text { produced } \\
\qquad I_{N_{4,2}}^{-}\end{array}$ & $\begin{array}{l}\text { Site waste } \\
\text { for recycling } \\
\text { per vehicle } \\
\text { produced } \\
I_{N_{5,2}}^{+}\end{array}$ & $\begin{array}{c}\text { Environmental } \\
\text { sustainability } \\
\text { index }\left(I_{S_{2}}\right) \\
I_{S_{2}=}\left(\sum_{i} I^{+}{ }_{N_{i, 2}}-\sum_{i} I_{N_{i, 2}}^{-}\right)\end{array}$ \\
\hline 1999 & 0.722 & $\mathrm{n} / \mathrm{a}$ & 0.686 & $\mathrm{n} / \mathrm{a}$ & $\mathrm{n} / \mathrm{a}$ & -1.408 \\
\hline 2000 & 1.000 & 0.743 & 0.714 & 0.588 & $\mathrm{n} / \mathrm{a}$ & -3.045 \\
\hline 2001 & 0.952 & 1.000 & 1.000 & 1.000 & $\mathrm{n} / \mathrm{a}$ & -2.952 \\
\hline 2002 & 0.854 & 0.829 & 0.857 & 0.591 & $\mathrm{n} / \mathrm{a}$ & -3.131 \\
\hline 2003 & 0.727 & 0.200 & 0.143 & 0.234 & $\mathrm{n} / \mathrm{a}$ & -1.304 \\
\hline 2004 & 0.484 & 0.200 & 0.143 & 0.264 & 0.000 & -1.091 \\
\hline 2005 & 0.412 & 0.143 & 0.000 & 0.180 & 0.248 & -0.487 \\
\hline 2006 & 0.334 & 0.171 & 0.143 & 0.220 & 0.346 & -0.522 \\
\hline 2007 & 0.279 & 0.086 & 0.000 & 0.152 & 0.617 & 0.100 \\
\hline 2008 & 0.223 & 0.057 & 0.071 & 0.139 & 0.737 & 0.246 \\
\hline 2009 & 0.000 & 0.229 & 0.429 & 0.122 & 1.000 & 0.221 \\
\hline 2010 & 0.275 & 0.143 & 0.286 & 0.090 & 0.813 & 0.020 \\
\hline 2011 & 0.383 & 0.086 & 0.143 & 0.063 & 0.718 & 0.043 \\
\hline 2012 & 0.373 & 0.057 & 0.069 & 0.044 & 0.736 & 0.193 \\
\hline 2013 & 0.310 & 0.050 & 0.132 & 0.011 & 0.681 & 0.177 \\
\hline 2014 & 0.157 & -0.001 & 0.082 & -0.001 & 0.765 & 0.527 \\
\hline
\end{tabular}

Table 6. Determination of the environmental sustainability index $\left(I_{S_{2}}\right)$ 
The social sustainability index was computed using the Equation 6 in its original format (Table 7). As regards the type of impact of the social indicators on sustainability, the normalized indicator "Number of lost-time incidents" $\left(I_{N_{1,3}}^{-}\right)$h as a negative impact on sustainability and both "Number of training days per employee" $\left(I_{N_{2,3}}^{+}\right)$and "Total number of employees = Automotive manufacturing + Automotive supply and use" $\left(I_{N_{3,3}}^{+}\right)$h ave a positive impact.

\begin{tabular}{|c|r|r|r|r|}
\hline & $\begin{array}{c}\text { Number of lost-time } \\
\text { incidents } \\
I_{N_{1,3}}^{-}\end{array}$ & $\begin{array}{c}\text { Number of training } \\
\text { days per employee } \\
I_{N_{2,3}}^{+}\end{array}$ & $\begin{array}{c}\text { Total number of } \\
\text { employees } \\
I_{N_{3,3}}^{+}\end{array}$ & $\begin{array}{c}\text { Social sustainability } \\
\text { index }\end{array}$ \\
\hline 1999 & $\mathrm{n} / \mathrm{a}$ & $\mathrm{n} / \mathrm{a}$ & 0.979 & 0.866 \\
\hline 2000 & $\mathrm{n} / \mathrm{a}$ & $\mathrm{n} / \mathrm{a}$ & 0.850 & 0.866 \\
\hline 2001 & $\mathrm{n} / \mathrm{a}$ & $\mathrm{n} / \mathrm{a}$ & 0.783 & 0.850 \\
\hline 2002 & 0.998 & $\mathrm{n} / \mathrm{a}$ & 0.843 & -0.215 \\
\hline 2003 & 1.083 & 1.000 & 0.723 & 1.351 \\
\hline 2004 & 0.628 & 0.308 & 0.740 & 1.200 \\
\hline 2005 & 0.459 & 0.538 & 0.681 & 1.089 \\
\hline 2006 & 0.407 & 0.154 & 0.644 & 0.936 \\
\hline 2007 & 0.291 & 0.077 & 0.438 & 0.642 \\
\hline 2008 & 0.204 & 0.311 & 0.047 & 0.245 \\
\hline 2009 & 0.198 & 0.692 & 0.122 & 0.141 \\
\hline 2010 & 0.019 & 0.455 & 0.188 & 0.298 \\
\hline 2011 & 0.110 & 0.504 & 0.018 & 0.141 \\
\hline 2012 & 0.123 & 0.258 & 0.291 & 0.437 \\
\hline 2013 & 0.147 & -0.019 & 0.475 & 0.474 \\
\hline 2014 & -0.001 & 0.652 & & 0.45 \\
\hline
\end{tabular}

Table 7. Determination of the social sustainability index $I_{S_{3}}$ 


\section{$6^{\text {th }}$ Step - Computing the Supply Chain Sustainability Index}

The sustainability index for the UK automotive supply chain was computed by aggregating the weighted sub-indices into a unique value using the Equation 7 (Table 8). The aggregation method used in this research to compute the supply chain sustainability index was the Simple Additive Weighting (SAW) method, also known as the weighted sum method.

\begin{tabular}{|c|c|c|c|c|}
\hline $\begin{array}{l}W_{1}=0,32 \\
W_{2}=0,46 \\
W_{3}=0,23\end{array}$ & $\begin{array}{l}\text { Economic } \\
\text { sustainability index } \\
\qquad I_{S_{1}} \\
\text { (1) }\end{array}$ & $\begin{array}{l}\text { Environmental } \\
\text { sustainability index } \\
\qquad \begin{array}{c}I_{2} \\
(2)\end{array}\end{array}$ & $\begin{array}{l}\text { Social sustainability } \\
\text { index } \\
\qquad I_{S_{3}} \\
(3)\end{array}$ & $\begin{array}{c}\text { Supply Chain } \\
\text { sustainability index } \\
I_{S j} \text { SUST } \\
(4)=(1) * W_{1}+(2) * W_{2}+(3) * W_{3}\end{array}$ \\
\hline 1999 & 1.390 & -1.408 & 0.979 & 0.022 \\
\hline 2000 & 0.975 & -3.045 & 0.866 & -0.889 \\
\hline 2001 & 0.929 & -3.952 & 0.850 & -1.325 \\
\hline 2002 & 1.170 & -3.131 & -0.215 & -1.115 \\
\hline 2003 & 1.232 & -1.304 & 0.760 & -0.031 \\
\hline 2004 & 1.294 & -1.091 & 1.351 & 0.223 \\
\hline 2005 & 1.276 & -0.487 & 1.200 & 0.460 \\
\hline 2006 & 1.203 & -0.522 & 1.089 & 0.395 \\
\hline 2007 & 1.548 & 0.100 & 0.936 & 0.756 \\
\hline 2008 & 1.483 & 0.246 & 0.642 & 0.735 \\
\hline 2009 & 1.376 & 0.221 & 0.245 & 0.598 \\
\hline 2010 & 1.097 & 0.020 & 0.141 & 0.392 \\
\hline 2011 & 1.624 & 0.043 & 0.298 & 0.608 \\
\hline 2012 & 1.748 & 0.193 & 0.141 & 0.681 \\
\hline 2013 & 2.387 & 0.177 & 0.437 & 0.946 \\
\hline 2014 & 2.661 & 0.527 & 0.474 & 1.203 \\
\hline
\end{tabular}

Table 8. Supply chain sustainability index

\section{Results and Discussions}

After the application of the framework, the suggested sustainability index and the three sub-indexes computed it is possible to highlight some results. Considering each dimension of sustainability (economic, social and environmental) and bearing in mind the time horizon of the research it is possible to state that besides some fluctuations the economic sustainability index presents a growing trend, mainly after 2010 (Figure 1). 


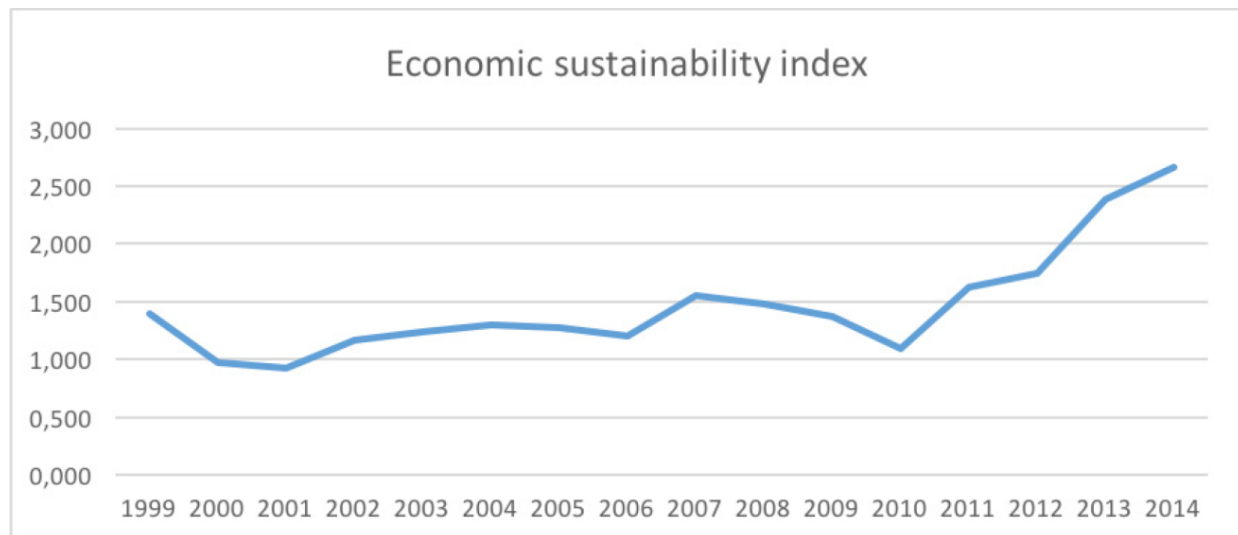

Figure 1. Evolution of Economic sustainability index

This evolution is associated to the behavior of the three indicators that form the economic sustainability dimension, that are: automotive manufacturing sector turnover, automotive sector value added and total number of new cars produced. The behaviour of the economic sustainability could be explained by governments policies, after the reduction in car sales after 2007, that introduced new temporary measures, including subsidised credit facilities and bonuses for replacing old cars by new cars as well as loans, loan guarantees and subsidies to firms in difficulty. In return, governments have sometimes required the production of more energy-efficient cars (OECD, 2010). These measures contributed to improve the economic sustainability of the UK automotive SC. Also, the number of models, body styles, and variants of cars have increased over time influencing negatively the economic performance of the automotive industry in the UK (Wells, 2013) The automotive industry followed some strategies to overcome this problem, such as: i) globalisation as a way of expanding market, ii) consolidation to share costs over a greater number of brands and models; and iii) platform strategies to reduce vehicle development costs. These strategies were adopted mainly after 2010 which contributed to improve the economic performance of this kind of industry.

As regards the evolution of the environmental sustainability index for the $25 \mathrm{UK}$ automotive companies from 1999 to 2014 it has been very positive (Figure 2) presenting a considerable growing trend after 2002. Before the year of 2006 this index presents a negative behaviour and after that an environmentally friendly behaviour was adopted contributing for a positive grow until 2014. This means that across this time the indicators with a negative impact (Total combined energy use, Water use per vehicle produced, $\mathrm{CO}_{2}$ equivalent per vehicle produced and Waste to landfill per vehicle produced) decreased and the indicator reflecting a more environmentally conscious behaviour (Site waste for recycling per vehicle produced) was improved. The growing concern of the UK automotive industry with the negative impacts of their operations on environment was converted in a priority. According to Wells and Nieuwenhuis (2012) the automotive industry constitutes a major consumer 
of raw materials such as steel, aluminium, plastic, magnesium die casting and significant proportions of other materials such as rubber and copper These materials may be recycled, but in reality only a very small proportion is ever recycled back into cars: most are "downcycled" into less technically demanding applications, or indeed simply thrown away. Also, fuel efficiency in contemporary cars is a function of the thermal efficiency of the engine and powertrain (how well it converts the energy in the fuel into useful energy at the wheels), and the overall design of the vehicle and particularly the aerodynamic efficiency and weight of the vehicle.

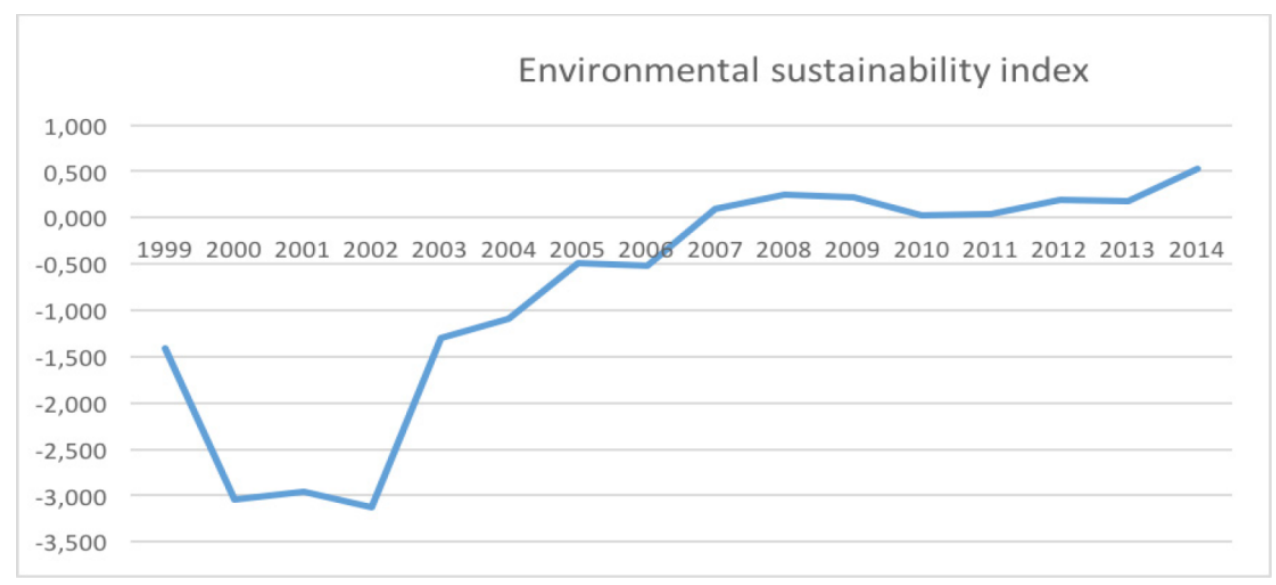

Figure 2. Evolution of the environmental sustainability index

According to the Figure 3 and considering the research indicators, the UK automotive industry presents a quite irregular social behaviour. Higher concerns with social aspects of the industry is verified mainly between 2002 and 2004. This means that during this period in the UK automotive companies the number of lost-time incidents decreased, the number of training days per employee increased and the total number of employees $\mathrm{h}$ as also increased. After that, the tendency was to decrease but with a small grow just after 2012. It is a reality that the automotive industry has made considerable progress in terms of working conditions and practices, although with cycle times very short. Moreover, employment is not stable. Many plants have introduced a wide range of "flexibility" arrangements with the workforce. One important problem is that because plants are very large, work and wealth generation is concentrated into particular locations leading to cities being heavily dependent upon car production (Weels, 2013). 


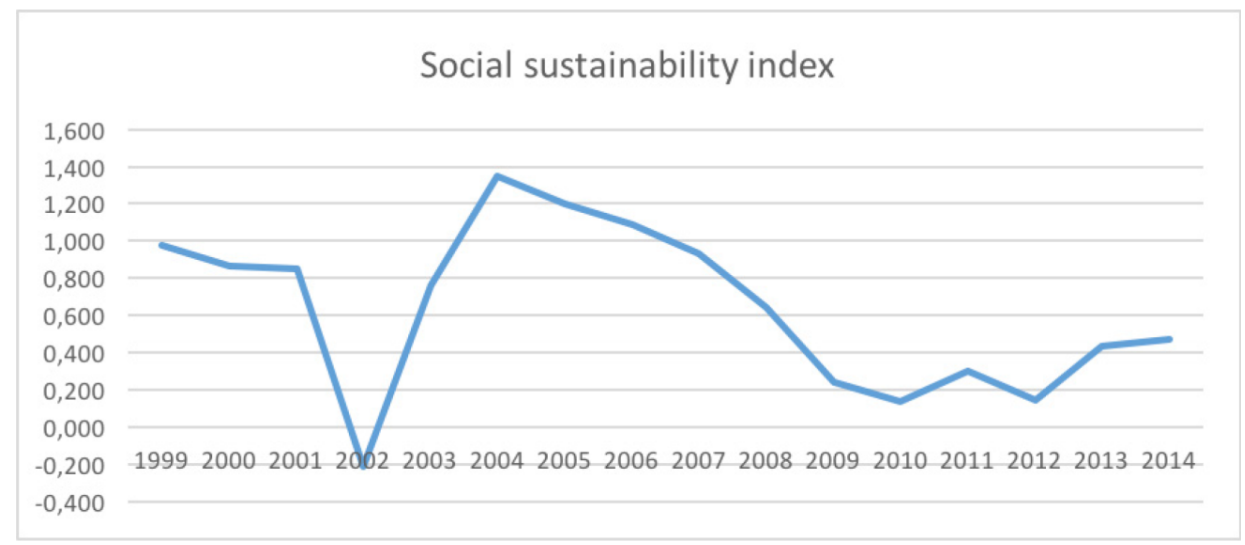

Figure 3. Evolution of the social sustainability index

As regards, the sustainability index for the UK automotive supply chain, as can be seen in Figure 4 it has improved during the last decade. During the first years of this century the automotive industry was concerned mainly with environmental issues. Since 2004 an improvement in the sustainable behaviour was observed reflecting a grown in the SC sustainability index. The year of 2009 was not so good in terms of sustainability representing a decrease in the sustainability index value.

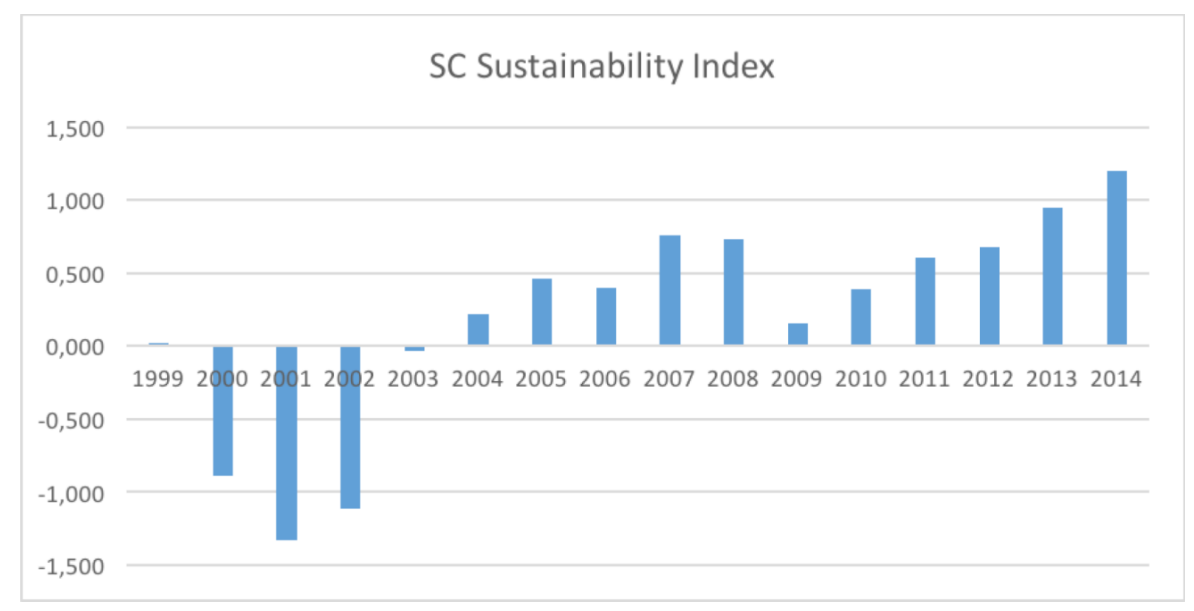

Figure 4. Evolution of the SC sustainability index

The Figure 5 illustrates the sustainability behaviour of the UK automotive SC (I $\left.I_{S \_} S U S T\right)$ using the proposed sustainability index and during the research time horizon. Looking at the graphic it is possible to see that the sustainability behaviour of the SC in the UK has been slowly improved all over the years. It reflects the aggregated behavior from the economic, environmental and social dimension of sustainability and considering their weights. The environmental sustainability presents the worst values, being negative during the period between 1999 and 2004. After that the sustainability sub-index has increased which 
reflects more concern with the environment, mainly in the quantity of combined energy used, the quantity of water, $\mathrm{CO}_{2}$ equivalent, waste to landfill and site waste for recycling per vehicle produced.

The economic dimension of sustainability has a positive behaviour during the research time horizon but in 2009 (Figure 5). The social dimension presents positive values which mean that the automotive supply chain in UK during the period of analysis has a social responsibility behaviour investing in improving the working conditions by decreasing the "Number of lost-time incidents" and improving the "Number of training days per employee" and also the "Total number of employee".

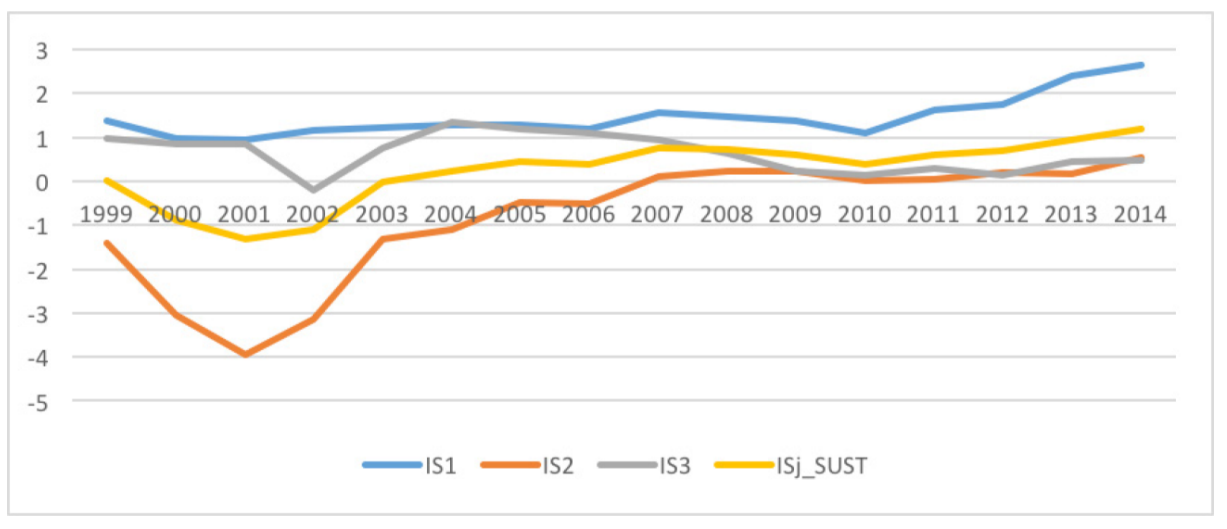

Figure 5. Comparison of sustainability sub-indices and SC sustainability index

However it is important to note that the sustainability behaviour of the UK automotive SC is influenced by the sustainability indicators used, the weighting of each sustainability dimension and also the kind of the research companies.

\section{Conclusion}

Sustainability has received much attention, becoming a strategic topic not only for countries but also for individual organizations and supply chains. Sustainability consists of managing the triple bottom line and includes decision-making that simultaneously takes into consideration economic, social, and environmental concerns.

Companies are often less concerned with the social and environmental dimensions of sustainability as they tend to think of corporate social responsibility in generic ways. The existing approaches to social and environmental initiatives are fragmented and disconnected from strategy which can lead to conflicting social, environmental, and economic objectives. Instead organizations must explicitly link environmental, 
social, and economic goals within a broader strategic perspective to ensure that environmental and social initiatives are reflected in the triple bottom line.

This paper aims to assess the sustainability of UK automotive supply chain using the framework adapted from Salvado et al. (2015) to compute the SC sustainability index. The proposed index results from the aggregation of economic, social and environmental indicators and use different weights for each sustainability dimension. Weights are chosen using the Delphi technique, with a panel formed by academics and professionals from the automotive industry. This methodology helps adjust the sustainability index to the reality of the industry and makes index construction a more dynamic process.

In this way, managers can use the sustainability index to help adjust their SC' behaviour and improve economic, social and environmental performance. Also, the proposed framework is quite flexible making possible to adjust the determination of the sustainability index to the reality of the SC by choosing different indicators and using their own professionals for indicators' weighting. Moreover, once stabilized the sustainability index a Benchmarking analysis could be performed and the best and worst performer in each sustainability dimension identified.

Attending to the results reached with the application of the sustainability index it can be stated that the sustainability of the UK automotive supply chain has been improved during the last decade. During the first years of this century the automotive industry was concerned mainly with economic issues specially with sector turnover, value added and number of cars produced.

From 2002 an improvement in the sustainability index of the UK automotive industry was observed contributing to this tendency a more concern on environmental issues which reflects new behaviours in terms of combined energy used, water used per vehicle, $\mathrm{CO}_{2}$ equivalent per vehicle produced, waste to landfill per vehicle produced and site waste for recycling per vehicle produced.

The suggested approach gives a deeper knowledge on the sustainability behaviour of the UK automotive $\mathrm{SC}$ considering the integration of the economic, social and environmental dimensions.

Besides the advantages of using the proposed index to assess the level of sustainability of UK automotive SC it presents also some limitations such as: the selection of the economic, social and environmental indicators should be performed with the involvement of other important stakeholders such as the Non-Governmental Organizations (NGO's), consumer organisations, fuel producers, retailers. Moreover, data triangulation using other data' sources such as questionnaires and interviews with the human resources manager, the financial manager and the production manager should also be incorporated in order to a better selection of the sustainability indicators. More, the annual reports have been criticized in managerial-cognition research because they consider that they could be part of 
communication strategies performed by senior executives with external stakeholders (Arndt \& Bigelow, 2000).

Also, the proposed framework is only adjusted to the automotive industry since the economic, social and environmental indicators used to compute the SC' sustainability index is identified from the sustainability reports of the UK' automotive companies and their professionals made part of the panel Delphi.

While this study has been able to prove the feasibility of the approach, a case study considering several companies from different industries is the recommended next step. Such an application will help illustrate the applicability of the sustainability index for both individual companies and the supply chain. Also, other sectorial cases including sustainability analysis should be performed.

\section{References}

Ahi, P., \& Searcy, C. (2013). A comparative literature analysis of definitions for green and sustainable supply chain management. Journal of Cleaner Production, 52, 329-341.

https://doi.org/10.1016/j.jclepro.2013.02.018

Arndt, M., \& Bigelow, B. (2000). Presenting structural innovation in an institutional environment: Hospitals' use of impression management. Administrative Science Quarterly, 45, 494-522. https://doi.org/10.2307/2667107

Automotive Council UK (2013) - Technology Work Groups, Consensus Roadmaps and workstream feedback. Available online at: http://www.automotivecouncil.co.uk/wp-content/uploads/2013/09/D1MPS3-AutomotiveCouncilTech-Group-2.pdf (Acessed: 22 may 2016).

Automotive Council UK (2015). UK Automotive International Competitiveness Report 2015: Driving success - a strategy for growth and sustainability in the UK automotive sector.

Azapagic, A. (2004). Developing a framework for sustainable development indicators for the mining and minerals industry. Journal of Cleaner Production, 12(6), 639-662. https://doi.org/10.1016/S0959-6526(03)00075-1

Azapagic, A., Stamford, L., Youds, L., \& Barteczko-Hibbert, C. (2016) Towards sustainable production and consumption: A novel DEcision-Support Framework IntegRating Economic, Environmental and Social Sustainability (DESIRES). Computers and Chemical Engineering, 91, 93-103. 
Azevedo, S.G., Govindan, K., Carvalho, H., \& Cruz-Machado, V. (2013). Ecosilient Index to assess the greenness and resilience of the upstream automotive supply chain. Journal of Cleaner Production, 56, 131-146. https://doi.org/10.1016/j.jclepro.2012.04.011

Azevedo, S.G., Govindan, K., Carvalho, H., \& Cruz-Machado, V. (2012). An integrated model to assess the leanness and agility of the automotive industry. Resources Conservation Recycling, 66, 85-94. https://doi.org/10.1016/j.resconrec.2011.12.013

Barr, P., Stimpert, J., \& Huff, A.S. (1992). Cognitive change, strategic action, and organizational renewal. Strategic Management Journal, 13, 15-36. https://doi.org/10.1002/smj.4250131004

Bautista, S., Enjolras, M., Narvaez, P., Camargo, M., \& Morel, L. (2016). Biodiesel-triple bottom line (TBL): A new hierarchical sustainability assessment framework of principles criteria \& indicators (PC\&I) for biodiesel production. Part II-validation. Ecological Indicators, 69, 803-817. https://doi.org/10.1016/j.ecolind.2016.04.046

Beloff, B.R., \& Tanzil, D. (2006). Assessing impacts: overview on sustainability indicators and metrics. Environmental Quality Management, 15(4), 41-56. https://doi.org/10.1002/tqem.20101

Berns, M., Townend, A., Khayat, Z., Balagopal, B., Reeves, M., Hopkins, M., \& Kruschwitz, N. (2009). Sustainability and Competitive Advantage. MIT Sloan Management Review, 51(1), 19-26.

Beske, P., \& Seuring, S. (2014). Putting sustainability into supply chain management. Supply Chain Management, 19(3), 331-322. https://doi.org/10.1108/SCM-12-2013-0432

Camarillo, M., Stringfellow, W.T., Jue, M.B., \& Hanlon, J.S. (2012). Economic sustainability of a biomass energy project located at a dairy in California, USA. Energy Policy, 48, 790.

https://doi.org/10.1016/j.enpol.2012.06.020

Chan, A.P.C., Yung, E.H.K., Lam, P.T.I., Tam, C.M., \& Cheung, S.O. (2001). Application of Delphi method in selection of procurement systems for construction. Construction Management \& Economics, 19(7), 699-718. https://doi.org/10.1080/01446190110066128

Cherchye, L., Moesen, W., Rogge, N., \& Puyenbroeck, T.V. (2007). An Introduction to "Benefit of the Doubt" Composite Indicators. Social Indicators Research, 82(1), 111-145. https://doi.org/10.1007/s11205-0069029-7

Christofi, A., Christofi, P., \& Seleshi, S. (2012). Corporate sustainability: historical development and reporting practices, Management Research Review, 35(2), 157-172. https://doi.org/10.1108/01409171211195170 
Clivillé, V., \& Berrah, L. (2012). Overall performance measurement in a supply chain: towards a supplier-prime manufacturer based model. Journal of Intelligent Manufacturing, 23 (6), 2459-2469. https://doi.org/10.1007/s10845-011-0512-x

Delai, I., \& Takahashi, S. (2011). Sustainability measurement system: a reference model proposal. Social Responsibility Journal, 7(3), 438-471. https://doi.org/10.1108/17471111111154563

Dos Santos, S.F. \& Brandi, H.S. (2015). Model framework to construct a single aggregate sustainability indicator: an application to the biodiesel supply chain. Clean Technologies and Environmental Policy, 17(7), 1963-1973. https://doi.org/10.1007/s10098-015-0919-8

Downe-Wamboldt, B. (1992). Content analysis: Method, applications, and issues. Health Care for Women International, 13, 313-321. https://doi.org/10.1080/07399339209516006

Erdener, C.B., \& Dunn, C.P. (1990). Content analysis. In Huff A.S. (Ed.). Mapping strategic thought. Chichester: Wiley. 291-300.

Erol, I., Sencer, S., \& Sari, R. (2011). A new fuzzy multi-criteria framework for measuring sustainability performance of a supply chain. Ecological. Economics, 70(6), 1088-1100.

https://doi.org/10.1016/j.ecolecon.2011.01.001

Gasparatos, A., El-Haram, M., \& Horner, M. (2008). A critical review of reductionist approaches for assessing the progress towards sustainability. Environmental Impact Assess Review, 28(4-5), 286-311. https://doi.org/10.1016/j.eiar.2007.09.002

Gimenez, C., \& Tachizawa, E.M. (2012). Extending sustainability to suppliers: A systematic literature review. Supply Chain Management: An International Journal, 17(5), 531-543.

https://doi.org/10.1108/13598541211258591

Gopal, P.R.C., \& Thakkar, J. (2012). A review on supply chain performance measures and metrics: 2000-2011. International Journal of Productivity and Performance Management, 61(5), 518-547. https://doi.org/10.1108/17410401211232957

Gray, R.H., Milne, M., \& Buhr, N. (2014). Histories, Rationales, Voluntary Standards and Future Prospects or Sustainability Reporting: CSR, GRI, IIRC and Beyond. In Bebbington, J., Unerman, J., \& O’Dwyer, B. (Eds.). Sustainability Accounting and Accountability. London: Routledge. 51-71.

GRI (2013). G4 Sustainability Reporting Guidelines - Reporting Principles and Standard Disclosures, Global Reporting Initiate. www.griorg 
Hai, L.T., Hai, P.H., Ha, P.T.T., Ha, N.M., Dai, L.T., Hoa, P.V. et al. (2014). A System of Sustainability Indicators for the Province of Thai Binh, Vietnam. Social Indicators Research, 116(3), 661-679. https://doi.org/10.1007/s11205-013-0315-x

Harris, J., Wise, T., Gallagher, K., \& Goodwin, N. (2001). A Survey of Sustainable Development: Social and Economic Dimensions. Washington: Island Press.

Hatefi, S.M., \& Torabi, S.A. (2010). A common weight MCDA-DEA approach to construct composite indicators. Ecological Economics, 70(1), 114-120. https://doi.org/10.1016/j.ecolecon.2010.08.014

Herzig, C., \& Godemann, J. (2010). Internet-supported sustainability reporting: Developments in Germany. Management Research Review, 33, 1064-1082. https://doi.org/10.1108/01409171011085903

Israel, D. (2009). Data Analysis in Business Research: A Step-By-Step Nonparametric Approach. Sage Publications Pvt. Ltd.

Kabanoff, B., \& Keegan, J. (2007). Studying Strategic Cognition by Content Analysis of Annual Reports: A Validation Involving Firm Innovation. In Chapman, R. (Ed.). Proceedings Managing Our Intellectual and Social Capital: 21st ANZAM 2007 Conference. Sydney, Australia. 1-14.

Kang, S.M., Kim, M.S., \& Lee, M. (2002). The trends of composite environmental indexes in Korea. Journal of Environmental Management, 64(2), 199-206. https://doi.org/10.1006/jema.2001.0529

Kapur, N., \& Dhanrajani, S. (2013). Sustainability of Indian Public Sector Banks \& Housing Finance Corporations through the 2008 Financial Crisis: A Case Study on the Role of Underwriting, Capital Adequacy \& Borrower Characteristics. Indian Journal of Economics and Business, 12(1), 13.

Kogg, B., \& Mont, O. (2012). Environmental and social responsibility in supply chains: The practise of choice and inter-organisational management. Ecological Economics, 83, 154-163. https://doi.org/10.1016/j.ecolecon.2011.08.023

Krajnc, D., \& Glavič, P. (2005). A model for integrated assessment of sustainable development. Resources Conservation and Recycling, 43(2), 189-208. https://doi.org/10.1016/S0921-3449(04)00120-X

Labuschagne, C., \& Brent, A. (2005). Sustainable project life cycle management: the need to integrate life cycles in the manufacturing sector. International Journal of Project Management, 23, 159-168. https://doi.org/10.1016/j.ijproman.2004.06.003

Labuschagne, C., Brent, A.C., \& van Erck, R.P.G. (2005). Assessing the sustainability performances of industries. Journal of Cleaner Production, 13(4), 373-385. https://doi.org/10.1016/j.jclepro.2003.10.007 
Liew, W.L., Hassim, M.H. \& Denny, K.S.N. (2015). Sustainability assessment framework for chemical production pathway: Uncertainty analysis. Journal of Environmental Chemical Engineering, 54(50), 12615-12629.

Linstone, H.A., \& Turoff, M. (1975). Introduction. In Linstone, H.A., \& Turoff, M. (Eds.). The Delphi method: Techniques and applications. Reading, MA: Addison-Wesley Publishing Company. 3-12.

López, M.V., García, A., \& Rodríguez, L. (2007). Sustainable Development and Corporate Performance: A Study Based on the Dow Jones Sustainability Index. Journal of Business Ethics, 75(3), 285-300. https://doi.org/10.1007/s10551-006-9253-8

Matopoulos, A., \& Bourlakis, M. (2010). Sustainability practices and indicators in food retail logistics: findings from an exploratory study. Journal on Chain and Network Science, 10(3), 207-218. https://doi.org/10.3920/JCNS2010.x179

Moreno-Pires, S., \& Fidélis, T. (2012). A proposal to explore the role of sustainability indicators in local governance contexts: The case of Palmela, Portugal. Ecological Indicators, 23, 608-615. https://doi.org/10.1016/j.ecolind.2012.05.003

Nardo, M., Saisana, M., Saltelli, A., \& Tarantola, S. (2005). Tools for Composite Indicators Building. Ispra: Joint Research Centre.

Niemeijer, D. (2002). Developing indicators for environmental policy: data driven and theory driven approaches examined by example. Environmental Science Policy, 5(2), 91-103. https://doi.org/10.1016/S14629011(02)00026-6

OECD (2010). The automotive industry in and beyond the crisis. In OECD Economic Outlook, 2009(2), OECD publishing.

Orsato, R., \& Wells, P. (2007). The Automobile Industry \& Sustainability. Journal of Cleaner Production, 15(11-12), 989-993. https://doi.org/10.1016/j.jclepro.2006.05.035

Pava, M.L. (2007). A response to getting to the bottom of triple bottom line. Business Ethics Quarterly, 17(1), 105. https://doi.org/10.5840/beq200717116

Penfield, P. (2014). Transformative Steps for Supply Chain Sustainability. Supply Chain Management Review, 18(2), 20-25.

Pérez, V., Guerrero, F., González, M., Pérez, F., \& Caballero, R. (2013). Composite indicator for the assessment of sustainability: The case of Cuban nature-based tourism destinations. Ecological Indicators, 29, 316-324. https://doi.org/10.1016/j.ecolind.2012.12.027 
Perry, C. (1998). Processes of a case study methodology for postgraduate research in marketing. European Journal of Marketing, 32(9/10), 785-802. https://doi.org/10.1108/03090569810232237

Petrescu-Mag, R.M., Petrescu, D.C., \& Muntean, O.L. (2015). Environmental Law: The Dynamics of Application and Control Processes. Environmental Policy and Law, 45(6), 310-319.

Ramirez, B., West, D.J., \& Costell, M. (2013). Development of a culture of sustainability in health care organizations. Journal of Health Organization and Management, 27(5), 665-672. https://doi.org/10.1108/JHOM$11-2012-0226$

Resta, B., Dotti, S., Pinto, R., Bandinelli, R., Rinaldi, R., \& Ciarapica, F.E. (2014). Practices for environmental sustainability in the textile, clothing and leather sectors: The Italian case. International Journal of Operations and Quantitative Management, 20(3), 193-225.

Rowe, G., \& Wright, G. (1999). The Delphi technique as a forecasting tool: issues and analysis. International Journal of Forecasting, 15, 353-375. https://doi.org/10.1016/S0169-2070(99)00018-7

Rowley, J. (2002). Using case studies in research. Management Research News, 25(1), 16-27. https://doi.org/10.1108/01409170210782990

Salvado, M., Azevedo, S., Matias, J.C.O. \& Ferreira, L. (2015). Proposal of a sustainability index for the automotive industry. Sustainability, 7(2), 2113-2144. https://doi.org/10.3390/su7022113

Sarkis, J., (2003). A strategic decision framework for green supply chain management. Journal of Cleaner Production, 11, 397-409. https://doi.org/10.1016/S0959-6526(02)00062-8

Savino, M.M., Manzini, R., \& Mazza, A. (2015). Environmental and economic assessment of fresh fruit supply chain through value chain analysis. A case study in chestnuts industry. Production Planning \& Control: The Management of Operations, 26(1), 1-18. https://doi.org/10.1080/09537287.2013.839066

Schaltegger, S., \& Burritt, R. (2014) Measuring and managing sustainability performance of supply chains: Review and sustainability supply chain management framework. Supply Chain Management, 19(3), 241-232. https://doi.org/10.1108/scm-02-2014-0061

Searcy, C., Karapetrovic, S., \& McCartney, D. (2005). Designing sustainable development indicators: analysis for a case utility. Measuring Business Excellence, 9(2), 33-41. https://doi.org/10.1108/13683040510602867

Seuring, S., \& Muller, M. (2008). From a literature review to a conceptual framework for sustainable supply chain management. Journal of Cleaner Production, 16(15), 1699-1710.

https://doi.org/10.1016/j.jclepro.2008.04.020 
Shafia, M.A., Mazdeh, M.M., Vahedi, M., \& Pournader, M. (2011). Applying fuzzy balanced scorecard for evaluating the CRM performance. Industrial Management \& Data Systems, 111(7), 1105-1135. https://doi.org/10.1108/02635571111170622

Shepherd, C., \& Günter, H. (2006). Measuring supply chain performance: current research and future directions. International Journal of Productivity and Performance Management, 55(3/4), 242-258. https://doi.org/10.1108/17410400610653219

Siche, J.R., Agostinho, F., Ortega, E., \& Romeiro, A. (2008). Sustainability of nations by indices: Comparative study between Environmental Sustainability Index, ecological footprint and the energy performance indices. Ecological Economics, 66(4), 628-637. https://doi.org/10.1016/j.ecolecon.2007.10.023

Sikdar, S.K. (2003). Sustainable development and sustainability metrics. AIChE Journal, 49(8), 1928-1932. https://doi.org/10.1002/aic.690490802

Singh, R.K., Murty, H.R., Gupta, S., \& Dikshit, A.K. (2007). Development of composite sustainability performance index for steel industry. Ecological Indicators, 7(3), 565-588.

https://doi.org/10.1016/j.ecolind.2006.06.004

Singh, R., Murty, H., Gupta, S., \& Dikshit, A. (2009). An overview of sustainability assessment methodologies. Ecological Indicators, 9(2), 189-212. https://doi.org/10.1016/j.ecolind.2008.05.011

Skouloudis, A., Evangelinos, K., \& Kourmousis, F. (2007). Benchmarking Greek sustainability reports according to the GRI reporting guidelines. In Kungolos, A., Aravossis, K., Karagiannidis, A., \& Samaras, P. (Eds.). Proceedings of the International Conference on Environmental Management, Engineering, Planning and Economics. Univeristy of Thessaly, Skiathos. 2305-2310.

Smith, M.D. (2008). Stochastic Frontier Models with Dependent Error Components. Econometrics Journal, 11, 172-192. https://doi.org/10.1111/j.1368-423X.2007.00228.x

Stake, R.E. (1995). The Art of Case Study Research: Perspective in Practice. London: Sage.

Taticchi, P., Tonelli, F., \& Pasqualino, R. (2013). Performance measurement of sustainable supply chains: A literature review and a research agenda. International Journal of Productivity and Performance Management, 62(8), 782-804. https://doi.org/10.1108/IJPPM-03-2013-0037

Tesch, R. (1990). Qualitative research: Analysis types and software tools. Bristol, PA: Falmer.

Tokos, H., Pintarič, Z.N., \& Krajnc, D. (2012). An integrated sustainability performance assessment and benchmarking of breweries. Clean Technologies and Environmental Policy, 14(2), 173-193. 
Tsoulfas, G.T., \& Pappis, C.P. (2008). A model for supply chains environmental performance analysis and decision making. Journal of Cleaner Production, 16(15), 1647-1657. https://doi.org/10.1016/j.jclepro.2008.04.018

Vachon, S., \& Klassen, R.D. (2006). Extending green practices across the supply chain: The impact of upstream and downstream integration. International Journal of Operations Production Management, 26(7), 795-821. https://doi.org/10.1108/01443570610672248

Veleva, V., \& Ellenbecker, M. (2001). Indicators of sustainable production: framework and methodology. Journal of Cleaner Production, 9(6), 519-549. https://doi.org/10.1016/S0959-6526(01)00010-5

Wackernagel, M. (2014). Comment on Ecological Footprint Policy? Land Use as an Environmental Indicator. Journal of Industrial Ecology, 18, 20-23. https://doi.org/10.1111/jiec.12094

Wang, S., Zhang, L., Liu Z., Liu G., \& Zhang, H.C. (2005). Study on the performance assessment of green supply chain. In 2005 IEEE International Conference on Systems, Man and Cybernetics, 1, 942-947. https://doi.org/10.1109/ICSMC.2005.1571267

Wang, Y., Lam, K. Harder, M.K., Ma, W., \& Yu, Q. (2013). Developing an indicator system to foster sustainability in strategic planning in China: A case study of Pudong New Area, Shanghai. Ecological Indicators, 29, 376-389. https://doi.org/10.1016/j.ecolind.2013.01.007

Wells, P., \& Nieuwenhuis, P. (2012). Transition failure: under- standing continuity in the automotive industry. Technological Forecasting and Social Change, 79, 1681-1692. https://doi.org/10.1016/j.techfore.2012.06.008

Wells, P. (2013) Sustainable business models and the automotive industry: A commentary. IIMB Management Review, 25(4), 228-239. https://doi.org/10.1016/j.iimb.2013.07.001

Woodrum, E. (1984). Mainstreaming content analysis in social science: Methodological advantage-obstacles and solutions, Social Science Research, 13(2), 1-9. https://doi.org/10.1016/0049089X(84)90001-2

Yin, R.K., (1984). Case Study Research: Design and Methods. Beverly Hills, Ca.: Sage Publications.

Yin, R.K. (2002). Case Study Research: Design and Methods (3 ${ }^{\text {rd }}$ Ed.). Applied Social Research Methods Series, 5. Sage Publications, Inc.

Yoon, K.P., \& Hwang, C.-L. (1995). Multiple Attribute Decision Making: An Introduction. Sage. https://doi.org/10.4135/9781412985161 
Zhou, L., Tokos, H., Krajnc, D., \& Yang, Y. (2012). Sustainability performance evaluation in industry by composite sustainability index. Clean Technology Environmental Policy, 14(5), 789-803. https://doi.org/10.1007/s10098-012-0454-9

Zhou, P., Ang, B.W., \& Poh, K.L. (2007). A mathematical programming approach to constructing composite indicators. Ecological Economics, 62(2), 291-297. https://doi.org/10.1016/j.ecolecon.2006.12.020

Journal of Industrial Engineering and Management, 2017 (www.jiem.org)

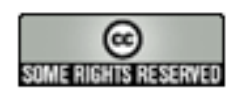

Article's contents are provided on an Attribution-Non Commercial 3.0 Creative commons license. Readers are allowed to copy, distribute and communicate article's contents, provided the author's and Journal of Industrial Engineering and Management's names are included. It must not be used for commercial purposes. To see the complete license contents, please visit http://creativecommons.org/licenses/by-nc/3.0/. 